\title{
Synchronization Between Act of Governance Administration and Act of Administrative Court to Develop Good Governance
}

\author{
Ayu Putriyanti \\ Faculty of Law \\ Diponegoro University \\ Semarang, Central Java, Indonesia \\ aputriyanti@yahoo.com
}

\begin{abstract}
This paper aimed to analyze Act No 30 The Year 2014 of Governance Administration is the material law to Acts of Administrative Court, as we knew the Acts No 5 Year 1986 of Administrative Court as procedural law . Some articles in Act No 30 Year 2014 are new and as guidance to implement the governance but it is not match with the procedural law. Regulations in Act No 5 The Year 1986 can not support the first Act. Both Acts should be synchronized and further law review because of law reasons which become contrary to some administrative law principles, administrative procedural law principles.
\end{abstract}

Keywords-Governance Administration, Administrative Court, develop good governance.

\section{INTRODUCTION}

The Government of Indonesia launched Act No. 30 Year 2014 of Governance Administration in order to build a good governance, law protection for citizenship against government's act. This Act is a brand new for Indonesia governments which strongly needed as guidance to implement the government's task. This is the material law to administrative procedural law under Act No. 5 Year 1986 which has been twice amendment by Act No. 9 Year 2004 and Act No. 51 Year 2009. The Administrative procedural law gives detail regulation if people will put the lawsuit against government's decree due to the misconduct of decree. Both Acts are needs to build a good governance due to the development of society, implementation of governance and another issue relates.

In Act No. 30 Year 2014 of Governance Administration there are some important points which relates with the competent of The Administrative Court and gives wider competent, follows by various object which can be used to make a lawsuit. This is an important points to rethinking of the aims for developing good governance.

The issue in this paper is the synchronization of both Acts to develop good governance. This paper analyze lack of law between both Acts, since there is no supporting regulation match with the existing condition. This conditions raise a new issue of the procedural law to implement some articles of The
Act No 30 Year 2014. It will become complicated today since there is still no supporting Acts.

\section{METHODS}

This article used yuridically normative method, by analyzed the concept of law. Act No 5 Year 1986 and its amendments obviously had different concepts with Act No 30 Year 2014, but both acts has the same goals to give justice and law enforcement .

\section{RESULT AND DISCUSSIONS}

\section{A. The Administrative Court.}

Indonesia followed the divisions of power into three part, legislative, executive and judicative. Each have their own authority but they have to implement the principle of check and balances. As a State Law, every government's act should be based on law and guarantee the human rights.

As inspired from Dutch legal system could be seen as we put Rechtsstaat as a basic concept in government and dominated by civil law system, that government's act should be based on law. Civil law basically put the codified law as important to rules all aspects. Thus, follow the development, the vital role of civil law today is to provide the foundations for legal institutions, doctrines and transactions at the basis of civil society and commercial law while balancing private law with legal obligations and responsibilities [1].

The judiciary system in Indonesia consists of Supreme Court and Constitutional Court. Under the Supreme Court there are four judiciary bodies as General Court, Religion Court, Military Court and Administrative Court. The aim of the Courts as guardian of human rights. This condition generally shows in the development country.

Based on civil law system, the Administrative Court formed under Act No 5 Year 1986 and applied 5 (five) years after legalized. The goals are to harmonized, synchronized relationship between government and society, gives protection against government's act, law enforcement in administrative law. The competence of the Court is to investigate, decide and settle administrative dispute, with some exceptional in the Act. 
The Court put an individual as Plaintiff and the government as Defendant, which could not change position. The aim is to cancel the government's decree, with or without compensation.

The Administrative Court established in country like Dutch, Germany, France, and some European country which used civil law system, and does not exist in USA, UK. In the Common Law System, there is no administrative court, all the administrative dispute will settle in general court. The main purpose of judicial control of administration in most nations, whether exercised by regular or special courts, is not to prevent administocracy as the term is used here but rather to protect the personal and property rights of individuals against violations by administrators.[2]

The model of administrative court are varies in many countries. Some countries follows the French model, the administrative court belongs to executive branch under the logic that the separation of powers requires a more restricted scope of action for the judiciary. On the common law interpretation put the administirative court under the judicial branch, with logic that any function of truly judicial nature must be exercised by judicial branch only, some countries use a hybrid model. [3] In Indonesia, Administrative Court formed by Act made between legislative and executive, but the position of the Court is under judicial branch. This based on idea that Administrative Court as a independence judicial body to control the government's action as an external control.

Relationship between good governance and the Administrative Court, cited from Bagir Manan, the government did not obey the Judge's verdict. He said that the law obedience to verdict as a participation and responsibility of the officer in the frame of good governance, in Lawrence Friedman's theory is called legal culture. [4] This behaviour is obstruct the law and against justice, and it did not support the effort of good governance.

Act No 5 Year 1986 and its amendments were regulate sanctions for disobey of judge's verdict, whereas there were some who did not put it into problem. This is contradiction, if people remains the law enforcement by the officer, but it did not supported with ethic and legal obedience. Law and authority have the same topics, that is ethic of politic or we can say ethic politic criticsm law and authority. Law without authority does not mean anything, neither State without law decline to the level of dehumanization since does not based on normative and authority outside the law is scared. [5] Culture of law related with ethic in politic and legal obedience, it means the behaviour of government to obey the judge's verdict is consummate of the ethic.

\section{B. Governance Administration}

Act No 30 Year 2014 of Governance Administration gives regulations and guidance to implement any government's act in public law. This act becomes important due to rapid changes in society, law, politics, economy which give impact to the government to issue the decree and regulation. Besides State Law, Indonesia also welfare state, in this function the government's intervention are needed with some restricted points.
Refer to United Nations Economic and Social Commissions for Asia and the Pacific, good governance has 8 (eight) majors characteristics, participatory, consensus oriented, accountable, transparent, responsive, effective and efficient, equitable and inclusive and follows the rule of law. [6] Good governance also based on a conviction that a system placing sovereignty in the hands of people is more likely to invest in people, channeling public resources to basic education, health care and social services. [7]

Good governance become the popular issue and it happens in the State inspired by Rule of Law or Rechtsstaat, both are accept this globalization issue. Good governance in rule of law have characteristic i.e., legal certainty and justice for people against public policy. The study of Salminen and Norrbacka assessed the general opinions, attitudes and expectation of trust good governance, and unethical actions, concludes that good governance practices enhance citizens trust in governance which is one of the core pillars upon which buildings of justice and political system are built. [8]

Based on the above study and the development of global politic, economy, information, Governments should begin to reform and rebuild organization by making regulation and the Administrative Court has an important role to supervise their duty.

Government also needs legitimacy to implement their policy and other government's action. Accordingly, legitimacy has become even more important in the public accpentance of governance actions. [9] .Legitimacy comes from the Act, that is the primary reason the importance of Act No 30 Year 2014 of Governance Administration.

\section{The synchronization between Act No 5 Year 1986 of Administrative Court and Act No 30 Year 2014 of Governance Administration to build good governance.}

System of law consists of substance, structure and culture. Without ignoring for structure and culture, in this paper, synchronization put highlight in the substance of law, because it become important for legal certainty, law enforcement and justice, i.e. the aims of law refer to Gustav Radburch. Synchronization of structure and culture will not take too much discussion, eventhough it have same proportion to build good governance.

The philosophy value of the Act No 30 Year 2014 of Governance Administration is to increase quality of public services based on principles of good governance, law enforcement, guardian of civil's right and principle of legality in governance. The Administrative Court duty is to build good governance starts since the Plaintiff put lawsuit, through process called Administratice Court Justice System, until the execution of judge's verdict.

The competence of Administrative Court become wider for some articles refer to Act No 30 Year 2014 of Governance Administration. First, Article 21 gives authority for the Court to accept, investigate and decide if there is any abuse of power by government's officer. The Court should decides in 21 workdays, and allows to appeal for judge's verdict in first level. Within 21 workdays, the Appeal Court should decide and 
the verdict is finally binding. The procedural law of the investigation abuse of power does not exist in the Act No 5 Year 1986 of Administrative Court. This lack of law brings uncertainty condition of law enforcement and good governance. In the meantime, Supreme Court published Supreme Court Rule No 4 Year 2015 of Procedural Law of Investigate Abuse of Power, and it is written the aim for filling in and prevent lack of law.

Second, in Article 53 there is a fictitious positive act, which able to become lawsuit. The same problem as previous, there is no procedural law in Act No 5 Year 1986 of Administrative Court and its amendments. The Supreme Court also published Supreme Court Rule No 5 Year 2015 of Procedural Law of Investigate Fictitious Positive Act. People may put lawsuit to governance if they already fully submit for request, but the government did not issued the decree. The Court will order the government to issue the decree. Third, Article 87 clearly mention the object of the Court has broader sense as it is written and gives consequences of its competency of judiciary, and Supreme Court has not issued any rules yet.

In the frame Rule of Law or Rechtsstaat, principle of legality has two important functions, as basic authority of governance and basic examination for the Court to know the authorized government. Principle of legality, authority and Administrative Court has a triangle relations to actualized good governance. Interaction between politic, economy, technology information and social problems has influenced to governance and judiciary across country.

The demand of good governance needs a new paradigm of Administrative Court. The Administrative Court should reform their procedural system and substance, otherwise it is difficult to face the challenge which become complete. Gar Yein Ng in his article, explain there should be an inter-disciplinary approach to judicial governance, by reintroduce the principle of accountability from a different perspectives than the traditional constitutional and legal perspective that focuses mainly upon judicial independence, procedural law and human rights. He said that a discipline in judicial governance should be developed, based on inter-disciplinary approach, to give one integrated picture of judicial governance. [10]

Refers to the role of Administrative Court in Indonesia, the comparison study above could be adjust and develop based on our ideology, constitution and law. This inter-disciplinary approach should developed, together with new paradigm of Administrative Law material and procedural. As a comparison study, New Approach in Dutch Administrative Court Proceeding requires judge to have an open and active attitude coupled with professional curiosity, it can be conclude interpersonal contact by the judge with parties involved become more and more important. [11]

Administrative law as material law has to consider the changing and development in theoritical and practical, many actor and factor surely influence the development. Giulio Napotalino in his article, said that politic, economic actors, institutional are not the only relevant players in administrative law, bureaucrats and judge deeply influence the development of administrative law as well. [12] This show that first, interdisciplinary approach is needed to build good governance, second, the material and procedural law are in the same position to change and develop to support good governance.

Synchronization of structure between Administration Court Justice System, government organization and related bodies. The regulation refers to their duty and task, should be based on the public interest, legal certainty and guarantee of human rights. For synchronize of the culture, it takes time to build legal obedience, ethic of politic and behaviour to respect of the law as a common habit for everyone.

Implementation of good governance also influenced by ethic, both politic and law. Sudikno Mertokusumo stated that law and ethic are two side of coin. Law address to human as social and bound with social norms, ethic address human as an individual that means with conscious mind. The ethic of politic and law as a basic norm to implement governance as good as build legal obedience, and it also culture of law.

The role of Court in changing of society, law, politics, economy is important in the international society so does in regional. As conclude by Irma Spahiu in her article, the role of the courts in transparency and access to information in two ways, first, courts are guardian in protecting citizen's rights of access and providing remedies against any abuse of such rights by government. Second, the role of the courts becomes exceptional when they act when they act as reformers in transforming access rights regimes. [13] In the modern governance, transparency is essentials and important. Citizens has rights to know the administrative procedure in issuing the decree, and also have rights to make a lawsuit . The Court, refer is the Administrative Court has an important part to build, and keep the government in their duty, to serve the people.

\section{CONCLUSION}

Synchronization of law consists of substance, structure and culture to achieve legal certainty, law enforcement and justice. Synchronization between Act No 5 Year 1986 of Administrative Court and Act No 30 Year 2014 of Governance Administration is strongly needed. There are some articles in Act No 30 Year 2014 of Governance Administration needs a clear regulation to implement, because it causes lack of law and hamper the law enforcement and good governance. Supreme Court has published Supreme Court Rule for minimizing the lack of law, but in the future it should support with commensurate Act.

Administrative Court has important role to build and achieve good governance. The Court as a guardian to civil's right against government's act, the competence of the Court should support with clear regulations. As administrative procedural law, the Court has obligation to actualize good governance. Government and Administrative Court put together to build good governance and achieve the national goals.

Good governance can be implemented by combining law and politic, it build ethic of politic and law as a basic norm as good as legal obedience. This manner as conscious mind for everyone without exception. 


\section{REFERENCES}

[1] M. Raff, "The importance of reforming civil law in formerly socialist legal systems," Int. Comp. Jurisprud., vol. 1, no. 1, pp. 24$32,2015$.

[2] A. Ranney, Governing: An Introduction to Political Science. 1996.

[3] S. López-Ayllón, A. García, and A. E. Fierro, "A ComparativeEmpirical analysis of administrative courts in Mexico," Mex. Law Rev., vol. 7, no. 2, pp. 3-35, 2015.

[4] B. Manan, "Mewujudkan Peradilan Yang Bersih dan Berwibawa Melalui Good Governance," in Menegakkan Hukum Suatu Pencarian, Jakarta: Asosiasi Advokat Indonesia, 20 09, pp. $273-$ 274.

[5] F. Magnis-Suseno, Etika Politik Prinsip-prinsip Moral Dasar Kenegaraan Modern. Jakarta: Gramedia, 1987.

[6] "http://www.unescap.org./sites/default/files/good-governance.pdf.".
[7] M. Kardos, "The reflection of good governance in sustainable development strategies," 8th Int. Strateg. Manag. Conf., vol. 58, pp. 1166-1173, 2012.

[8] M. Yousaf, F. Ihsan, and A. Ellahi, "Exploring the impact of good governance on citizens' trust in Pakistan," Gov. Inf. Q., vol. 33, no. 1, pp. 200-209, 2016.

[9] K. van den Bos, L. van der Velden, and E. A. Lind, "On the role of perceived procedural justice in citizens' reactions to government decisions and the handling of conflicts," Utr. Law Rev., vol. 10, no. 4, pp. 1-26, 2014.

[10] G. Y. Ng, "A discipline of judicial governance?," Ultr. Law Rev., vol. 7, no. 1, pp. 102-116, 2011.

[11] A. Verburg and B. Schueler, "Procedural justice in Dutch administrative court proceedings," Utr. Law Rev., vol. 10, no. 4, pp. 56-72, 2014.

[12] G. Napolitano, "Conflicts and strategies in administrative law," Int. J. Const. Law, vol. 12, no. 2, pp. 357-369, 2014.

[13] I. Spahiu, "Courts: An Effective Venue to Promote Government Transparency? The Case of the Court of Justice of the European Union," Utr. J. Int. Eur. Law, vol. 31, pp. 5-24, 2015. 